\title{
Mobile Devices in the Tourist Experience: Tijuana, Baja California, Mexico
}

\author{
Ana María Miranda Zavala \\ Autonomous University of Baja California, Mexico \\ amiranda@uabc.edu.mx \\ Isaac Cruz Estrada \\ Autonomous University of Baja California, Mexico \\ icruz@uabc.edu.mx \\ Margarita Ramírez Torres \\ Autonomous University of Baja California, Mexico \\ mramirez@uabc.edu.mx
}

This research aims to analyse the digital services and tools used in mobile devices and their benefit in the experience of tourists who arrive at Tijuana city. In addition, we test the following hypothesis: the use of digital services on mobile devices of tourists contributes to the experience in the destination. Methodology: 385 surveys made up of six dimensions were applied to tourists of the municipality. A correlation was made between the variables, the use of mobile services and satisfaction, and a factor analysis resulted in five components associated with the touristic experiences. A significant mean correlation between variables analysed was found. Likewise, the components of the factor analysis are immediacy of digital information and services at the destination; anticipated experiences; mobility; instant messaging; and provision of information via tourist apps. These technological factors used by visitors through smartphones benefit the tourist's experience in planning and during their stay in the visited place. The new needs of digital tourist require constant interaction with destination.

Keywords: tourists, mobile devices, ICT, digital services, tourism experience

(cc)BY-sA https://doi.org/10.26493/2335-4194.14.227-240

\section{Introduction}

All human experience happens at brain level, what is perceived through the senses is processed by chemicalelectrical impulses which are produced in neuronal communication; this implies that all experience of reality occurs within each individual (González-Damián, 2018). Thus, a personal event assumes an important emotional meaning, which is based on interaction with stimuli that are products or services consumed (Holbrook \& Hirschman, 1982), being able to pro- voke extraordinary experiences within a personal one (Arnould \& Price, 1993). For Pine II and Gilmore (2011) an economic factor is the experience, its values attract and involve customers by providing products and services that can generate memorable events. Regarding the tourist experience that the individual obtains during a trip, it cannot be characterized as a single one, but as a set of different situations, some of them obtained as a tourist and others not (GonzálezDamián, 2018). It should be noted that organizations 
and service providers in a destination seek to facilitate the development of an environment which allows for increasing the possibilities that people can transform their experiences into something memorable.

Likewise, experience is related to emotion: the tourist wants to discover, enjoy and connect with the local people and their customs, they want to go back to their place of origin with a lived history, with new emotions (Mazarrasa, 2016). The success of the experience offer in the destination is based on its being authentic, through differential characteristics of heritage, landscape, culture and populations (Rivera Mateos, 2013; Mazarrasa, 2016). Currently, technology allows travellers to have information of all kinds about the places that are of interest to them. Tourists have become more demanding and act interactively, with the purpose of finding a type of trip and activity different from the masses, demanding different products, alternative destinations and tailor-made services that are part of their experience (Rivera Mateos, 2013). In this sense, the evolution of mobile devices has increased in the last decade (Saura et al., 2017). According to Wang et al. (2012), they allow portable access to the Internet, they have high-resolution cameras for taking photos and videos, and geolocators to find the ideal route to the place of interest, as well as alarms, calendars, email, and the ability to install applications such as social networks. These latter sites have become a means of communication in promoting tourism. Companies use social media as an immediate channel for contact with customers, who have the opportunity to rate and share their experience in consuming the service or product during their stay in a destination (MendesThomaz et al., 2013; Katsoni, 2014).

As for tourism, Baja California is a great driver of economic growth and job creation. It represents $12 \%$ of the state's gross domestic product (GDP). The city of Tijuana is the border with the largest crossing in the world, and the cultural mix makes it a multifaceted, warm, and interesting city for tourists, according to the Tourism Secretariat (sEct U R, 2018). In the State Tourism Program 2015-2019, one of the established objectives was to promote the tourist offer and competitive assistance to boost the ecosystem of this sector in Baja California.
Technology has become a fundamental element in changing the way of travelling through a wide range of Internet sites and mobile applications that are used in preparing tourists' experiences. The evolution of the mobile market to an international scale has increased exponentially as well. Thus, the objective of the research is to analyse digital services and mobile device tools that benefit tourists' experiences when arriving at this border city.

\section{Literature Review}

Information and Communication Technologies (IC T s) have changed the way of promoting tourist sites, and electronic tourism (e-tourism) has emerged with the evolution of technologies, which includes the design, implementation, and application of IC Ts and e-commerce solutions, as well as the market structures of all the actors involved in the tourist experience (Werthner et al., 2015). By choosing the destination to visit, potential tourists are persuaded by the experiences and opinions of third parties, which are shared in digital media (Zeng \& Gerritsen, 2014; Kang \& Schuett, 2013). The information about a tourist site has to be continually updated on the different Internet platforms in order to remain a competitive destination in digital media and become an indispensable reference point for the visitor (Caro et al., 2015). Taking a trip involves a number of decisions that guarantee the continual enjoyment of the stay. Tourists have to choose from various options of accommodation, airlines, type of payment, and technological elements that must be considered from the beginning until the end of the trip. The companies that provide the services desired by travellers will gain an advantage by meeting people's expectations (SECT UR, 2018; Katsoni, 2014).

\section{Benefits of Mobile Devices for Experiences of Tourists}

The integration of IC TS in the tourism sector has benefitted travellers' experiences (Neuhofer et al., 2013). According to the Internet Association of Mexico (2018), smartphones have become the main means of connecting to the Internet in the country. The World Tourism Organization (UNWTO, 2015) and SECTUR (2018) clarify the importance that the development 
of mobile technology has had as a component to improve tourist experience, and to facilitate available services at the site. Through this technological equipment, it is possible to compare places of interest, organize the trip, review recommendations, check the weather before and during the trip, make reservations, locate various places and decide the best option to get there in the shortest time, among other functions and benefits that users find (Chang \& Shen, 2018). Therefore, tourist destinations and companies must be prepared to meet the mobility needs of today's travellers (Santillán-Núñez et al., 2015).

Ballesteros Díaz et al. (2014) and Chang and Shen (2018) point out that mobile technology has become a factor that contributes to consumer experience when purchasing services and products, with the opportunity to instantly assess the satisfaction via the Internet. People will remain in contact with friends and family to whom they will recommend their experiences or not. Smartphones have become a companion to travellers, used to obtain information in real time (Ricaurte Quijano et al., 2017). Through the installed applications, smartphones make it easier to move from the starting point to destinations in the city, adding various options that consider the disadvantages of each route. The technology available on mobile devices has become a fundamental component when people organize their trip; users feel connected and secure when they are aided by technology; they share their experience through photographs, videos, or simply indicate their current location in their social networks (Chang \& Shen, 2018).

Currently, communication strategies use advertising adapted to smart mobile devices as one of the strategic initiatives of digital marketing, since through the various platforms on the Internet it is possible to interact with tourist consumers who are looking for immediate answers. This exchange can mark the difference in purchase decisions of those who frequently use digital media (Santillán-Núñez et al., 2015; Internet Association of Mexico, 2018). Tourists' experiences can become more pleasant when using mobile technologies, which will accompany and guide them throughout their travel plan (Santillán-Núñez et al., 2015; Bonilla, 2013).

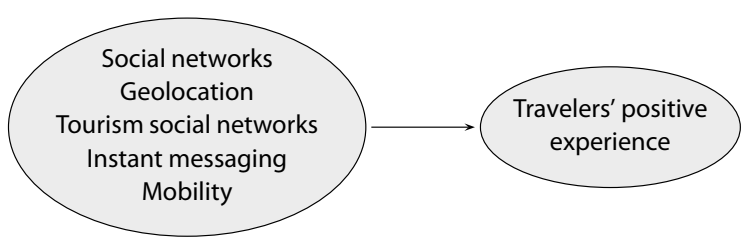

Figure 1 Mobile Services Applications

With smartphones, people can record and edit audios, videos, and texts, and access the Internet at the same time. This generates a history of consultation for other users, who can add a point of interest during their tour based on the information generated by the people who have become part of the web content generation (Iványi \& Bíró-Szigeti, 2019; Chang \& Shen, 2018).

Thus, some technological tools are used by tourists as an essential element to obtain information on the destination they wish to visit and then to create a travel itinerary, in order to ensure good experiences. Table 1 shows the approaches of some authors in relation to the digital services available, the reason why they are used, and their relation to the factors that prevail in tourists' experiences.

Based on the authors cited in the literature review and in Table 1, it can be asserted that the use of technological tools (social networks, applications for reservation of accommodation and restaurant services, geolocation programs and map tools, tourist social networks, etc.) used by people through smart mobile devices as support before and during their stay is positively related to the final tourist experience. Figure 1 shows a scheme that synthesizes this relationship and the verification of the hypothesis of this research, that the use of digital services on mobile devices contributes to the positive experience of tourists visiting the city of Tijuana. This, too, highlights the importance of digital media availability in tourist places that are of interest to visitors, which become essential for individuals in making decisions to attend and purchase services for which they have found data. Likewise, tourists have the opportunity to evaluate the service obtained in each of the phases of their travel itinerary, of which they anticipated various expectations. 
Table 1 Technological Services in Mobile Devices Related to Tourist Experience

\begin{tabular}{|c|c|c|}
\hline Authors & Digital services & Factors in the traveller exp. \\
\hline $\begin{array}{l}\text { Santillán-Núñez et al. } \\
\text { (2015); Saura et al. (2017); } \\
\text { Munar \& Jacobsen (2014); } \\
\text { Cervi (2019) }\end{array}$ & $\begin{array}{l}\text { Mobile social network apps such as Facebook, Twitter, and } \\
\text { Instagram are used by travellers to obtain information on } \\
\text { the tourist site, review comments, and seek information on } \\
\text { the experiences users have had in the destinations they wish } \\
\text { to visit. These digital media are a reference, in the purchase } \\
\text { decision phase and in the socialization of the experience in } \\
\text { the tourist place. }\end{array}$ & $\begin{array}{l}\text { Socialization of the experience. } \\
\text { Need for information. Com- } \\
\text { munication. Recommendation. } \\
\text { Anticipate experience. }\end{array}$ \\
\hline $\begin{array}{l}\text { Saura et al. (2017); Ricau- } \\
\text { rte Quijano et al. (2017) }\end{array}$ & $\begin{array}{l}\text { Geolocation tools such as Google Maps are used by tourists } \\
\text { to obtain information on the locations and routes of places } \\
\text { of interest, allowing the optimization of the transfer time } \\
\text { between the origin and destination during the trip. These ap- } \\
\text { plications installed on smart mobile devices satisfy travellers' } \\
\text { mobility needs. }\end{array}$ & $\begin{array}{l}\text { Mobility efficiency. Effectively } \\
\text { manage time during the stay at } \\
\text { the destination. }\end{array}$ \\
\hline $\begin{array}{l}\text { Litvin \& Dowling (2016); } \\
\text { Saura et al. (2017); } \\
\text { Kavoura \& Borges (2016); } \\
\text { Cervi (2019); Yu et al. } \\
(2016)\end{array}$ & $\begin{array}{l}\text { Travellers use tourist social networks such as Tripadvisor, Ex- } \\
\text { pedia, VirtualTourist, etc. to compare prices of hotels, flights, } \\
\text { payment options, etc. Potential travellers try to maximize } \\
\text { knowledge, searching for information on places of interest } \\
\text { available on the Internet. }\end{array}$ & $\begin{array}{l}\text { Search for information. Effi- } \\
\text { cient use of the travel budget. } \\
\text { Purchase decision based on } \\
\text { recommendations. Anticipate } \\
\text { experience. }\end{array}$ \\
\hline $\begin{array}{l}\text { Munar \& Jacobsen (2014); } \\
\text { Ricaurte Quijano et al. } \\
(2017)\end{array}$ & $\begin{array}{l}\text { Instant messaging apps like Facebook Messenger, WhatsApp, } \\
\text { are used by travellers to be in contact with their friends, fam- } \\
\text { ily, sharing information, and experiences of the tourist place. }\end{array}$ & $\begin{array}{l}\text { Communication with family } \\
\text { and friends. Proximity to its } \\
\text { digital social environment. } \\
\text { Share experiences. }\end{array}$ \\
\hline $\begin{array}{l}\text { Saura et al. (2017); Cervi } \\
\text { (2019); Dickinson et al. } \\
\text { (2014); Okazaki \& Hirose, } \\
\text { (2009); Wang et al. (2012) }\end{array}$ & $\begin{array}{l}\text { Travellers use m-tourism apps such as geolocation, reserva- } \\
\text { tions, Booking, Tripadvisor, Airbnb, Expedia, VirtualTourist, } \\
\text { etc., to obtain information on the destinations they want } \\
\text { to visit, to plan the easiest route and save time on transfers, } \\
\text { compare prices in accommodation, updating, and control } \\
\text { of the itinerary. These applications make tourism easier, } \\
\text { faster and cheaper, maximizing profitability and generating a } \\
\text { favourable experience for tourists. }\end{array}$ & $\begin{array}{l}\text { Control of travel itinerary. } \\
\text { Maximum cost-benefit prof- } \\
\text { itability. Service analysis. Con- } \\
\text { trol of available services. }\end{array}$ \\
\hline
\end{tabular}

\section{The Technological Approach in the Tourism Industry}

IC Ts have become an important factor in the tourism industry, which is why the UNW TO recommends that countries promote investment in innovation and digital advances in the tourism sector that provide opportunities for all (UNW TO, 2018). ICTs have become part of traveller's culture, which is related to new needs and unpredictable changes of tourists, they also have an important influence on travel cycle, from planning to assessing their experience (Ivars et al., 2016; Ferrá \& Cardona, 2015; Tafur et al., 2019).
With technological changes, tourism companies have been subjected to a dynamic that has shaped the business environment: companies need to have information quickly and efficiently to improve service management. The exponential advance of technologies induces companies to adapt to trends, which have among their main needs the constant exchange of information with consumers who use technological means in their daily lives. Digital marketing is used in the tourism industry as an effective means of reaching a cross-border market. The various technological tools favour the creation of value in the services or products, 
which are available to people who explore different options on the Internet on a daily basis (Lamberton \& Stephen, 2016; Domínguez Vila \& Araújo Vila, 2014). For Brumen et al. (2020), digital marketing focused on mobile devices is an area of opportunity for businesses. The interaction that people currently have with technologies leads to the need to use digital marketing to create effective and cheaper advertising, compared to traditional media. This trend has generated significant results, considering its availability to most of the population (Andrade Yejas, 2016; Daries-Ramón et al., 2016).

According to Velázquez Castro et al. (2018) and Narváez Castro and Villalobos Jiménez (2020), technology in the tourism industry has led to structural and functional changes, the entry of new actors, the development of new communication channels between providers and consumers, and the exchange of consumption experiences between people. According to the Ministry of Tourism (SECTUR), innovation allows companies to be more efficient, profitable, and guarantee continuous improvement in the traveller experience (SECTUR, 2013). The causes that drive innovation in the tourism sector are the unexpected decrease in visitors, goal achievement, increased productivity, product and service innovations, and penetration of new markets (Maráková \& Kvasnová, 2016).

In recent years, Mexico has been one of the favourite places for tourists in the world (UNWTO, 2018). Mexico has positioned itself among the top seven most visited countries in the world, receiving nearly 40 million tourists per year. The border cities have become important growth points in the country due to the importance of their industrial and service dynamics (Bringas et al., 2004). The city of Tijuana is the most populous municipality in the State of Baja California, with more than 1.7 million inhabitants according to data from the Planning Committee for the Development of the State (COPLADE, 2017). At the beginning of 2019, there was a $9 \%$ increase in the influx of tourists to the city compared to the previous year, according to data from the Tijuana Tourism and Convention Committee. However, IC Ts are one of the reasons that hinder tourism in Baja California, according to the Baja California State Program 2015-2019.
Furthermore, faced with an unprecedented challenge, the UNWTO, with the support of the World Health Organization (w HO), has asked innovators and entrepreneurs to provide new solutions in the aid of tourism, as it has been one of the sectors most affected by the COVID-19 pandemic (UNWTO, 2020). In midMarch 2020, tourism worldwide was paralyzed by the pandemic; international tourist arrivals decreased by $56 \%$ in the first month of the year, leading to losses of up to $\$ 320$ billion in tourism exports, which is more than three times what was lost in the global economic crisis of 2009 (Naciones Unidas, 2020). Countries and international organizations have undertaken various measures to mitigate the socio-economic impact of the pandemic, with the aim of stimulating the recovery of tourism, but the magnitude of the crisis requires additional efforts, innovation, maximizing the use of technology and continuous improvement of the processes employed in provision of its services (Naciones Unidas, 2020). Tourism organizations have implemented the management of technologies, new practices and protocols, with purpose of making their service more efficient, exercising with more interest the need for innovation to adapt to new tourism trends (De Freitas Coelho \& Feder Mayer, 2020).

According to lessons learned during the pandemic, it is essential to include processes and solutions with high added value in tourist destinations, relying on internet connectivity, IC т tools, and mobile devices, as well as the incorporation of various solutions that meet the needs and expectations of people (De Freitas Coelho \& Feder Mayer, 2020).

\section{The Proclivity to Use Technology in Purchase Decisions}

Advances in technology have caused the opening of new markets and growth in supply, so that companies are immersed in a globalized world, in a complex environment, and with increasing competition, and consumers have become more demanding, with volatile tastes (Velázquez Castro et al., 2018). Considering the current scene, the factors that influence purchase decisions (how to buy, why, what are the benefits sought) should be analysed. Knowing these aspects could be very useful for commercial managers 
in designing strategies and creating products based on client preferences, as well as in achieving better positioning in the market (Pérez-Almaguer et al., 2015). With the efficient application of technologies in companies, it is expected to obtain better results from existing services and allow the company to explore new markets (Arévalo-Avecillas et al., 2018).

Currently, the markets are very competitive and the loss of clients is very costly, therefore, developing a relational strategy based on acquiring and retaining clients is profitable (Egan, 2011; Sarmiento Guede \& Ferrão Filipe, 2019). In electronic environments, consumers look for brands that provide them with unique and personalized experiences (Zarantonello \& Schmitt, 2010) and more emotional activities. In addition, online user perception is influenced by design, emotions, environment, communication, community, security, and other characteristics intended to influence the final result of online interactivity (Constantinides, 2004; Sarmiento Guede \& Ferrão Filipe, 2019; Carrizo Moreira et al., 2017). Because electronic markets are characterized by uncertainty, one of the requirements for the progress of electronic commerce is trust (Chung \& Shin, 2010; Sukno \& Pascual, 2019; Davis et al., 2011). Once customers trust the brand, it is more likely that purchases will increase (Carrizo Moreira \& Silva, 2015).

Satisfaction is another important factor in the decision of online user consumption (Szymanski \& Hise, 2000; Chung \& Shin, 2010). This refers to judging experiences shared on the Internet that influence customer relationships with a product or service, customer loyalty, and their intention to buy online (Bigné et al., 2011). The experience in electronic commerce has a positive effect on user satisfaction (Constantinides, 2004). Electronic satisfaction is closely related to trust (Sukno \& Pascual, 2019; San Martín \& Pradanova, 2014).

The application of digital marketing in tourism has been growing intensely due to technological trends that are easily adapted to companies in this sector (Zhang et al., 2018; Nikunen et al., 2017). It is necessary to understand the consumer and their behaviour in the use of smartphones to develop marketing strategies (San Martín \& Pradanova, 2014). Apps for tourists, search engines, data analysis to measure experience, availability of reservations, or online sales and social networks are tools that frequently update new functions to meet customer needs (Lamberton \& Stephen, 2016; Andrade Yejas, 2016). An Internet user can consult various travel sites every day until the reservation is confirmed. This means that there is a lot of data that marketing specialists receive, with which they can prepare a different digital strategy that more effectively convinces potential travellers. Mobile technology offers advantages for purchases such as ubiquity, location, convenience, and personalization (Clarke, 2001).

The proper management of tourist companies' social networks is positively related to travellers' trust: with the information that the users obtain, they manage to solve certain doubts and then decide between the places they want to visit (Giraldo Cardona \& Martínez, 2017; Varkaris \& Neuhofer, 2017). Tools such as TripAdvisor are important for trip planning, however, Facebook is the main source of information before and during the trip. YouTube provides videos to analyse the destination and anticipate the experience. Messages on Twitter from individual experiences can influence many people's decisions. Instagram also shares images and videos but with special filters, in order to highlight some of the memorable moments during the trip (Huertas \& Marine-Roig, 2018). Social networks drive customers' buying decisions (Cvitić \& Plenković, 2018). Apps, programs, and/or social networks are available to be installed on smart mobile devices, which have become a satisfaction tool and guide for travellers. Consumers who trust e-buying will make more purchases (San Martín \& Pradanova, 2014).

\section{Methodology}

A qualitative survey technique was used for the research, and the size of the population studied was based on the latest 2017 report in the statistical and geographical yearbook of Baja California, which records the arrival of tourists in the municipality. The number of tourists recorded in the city of Tijuana in June and July was 217,173 (DataTur, n.d.), of which $92 \%$ are from California in the United States and the rest from Mexico (CEMDI, 2015). Based on this proportion, 355 sur- 
veys were applied to foreign tourists and 30 to domestic tourists, aged between 18 and 70 . It should be noted that the information obtained regarding the number of tourists arriving in Tijuana does not report the gender of the visitor; for this reason this variable was not considered to obtain the proportion. The instrument was applied to 385 tourists in the months of June and July of 2018, by simple random sampling at different tourist points and entrance to the city, to check the hypothesis: the use of digital services on mobile devices contributes to the positive experience of tourists. The sample size was obtained using the statistical formula for finite population, based on $95 \%$ confidence and 5\% of admitted error (Fischer \& Espejo, 2017; Malhotra, 2008).

Formula for finite population:

$$
\begin{aligned}
n & =\frac{N z^{2} p q}{(N-1) e^{2}+z^{2} p q} \\
& =\frac{217173 \times 1.96^{2} \times 0.5 \times 0.5}{(217173-1) \times 0.05^{2}+1.96^{2} \times 0.5 \times 0.5} \\
& =385 .
\end{aligned}
$$

Based on the revised literature, the survey is made up of six dimensions (see Table 2). Information is obtained on the sociodemographic profile, followed by the sources of information consulted to research the site; services used on mobile devices when visiting; how often digital services are used on mobile devices during the stay; how often the applications installed on smartphones are used, and which are important during the trip; and the level of satisfaction, based on digital services available on mobile devices during the visit.

Reliability analysis of the instrument was performed, using Cronbach's alpha with the spss 20 program. A reliability greater than 0.5 is considered acceptable (Oviedo \& Campo-Arias, 2005; Hernández Sampieri et al., 2014; Hinton et al., 2014). To validate the instrument, three dimensions were considered, which are made up of questions on a Likert scale (see Table 3). The sample corresponds to 385 surveys applied in the months of greatest influx of tourists in the year, June and July 2018, aimed at tourists visiting the city of Tijuana.

To manage and study the results database, the г в $\mathrm{M}$
SPSS Statistics 20 and MS Excel 2013 programs were used. First, a descriptive analysis was carried out; second, the verification of the relationship between the frequency with which tourists have access to the services available and the applications installed on smartphones during their stay, and the satisfaction that people find in the availability of digital services at the destination and in the companies that provide the services. Lastly, factor analysis was carried out, obtaining the technological factors based on the digital services and tools used by travellers on their smartphones, related to the experience of the tourist arriving in the city of Tijuana.

\section{Results}

Descriptive results are first discussed in order to identify the digital services and applications that the traveller uses before and during their stay in the destination, sampling the people who arrived in Tijuana between June and July 2018, of which $47.5 \%$ are female and $52.5 \%$ male. Travellers were asked about the digital services they frequently access from their mobile device during their stay: 95\% search for information on the services available, $92 \%$ use digital maps, a similar proportion mention inquiring about local restaurants, $91 \%$ check the weather, $90 \%$ look for recommendations in digital media, $83 \%$ like to make recommendations on social networks, and $78 \%$ look for transportation options through the mobile device and compare places of interest in the destination.

Regarding the apps that travellers use on their mobile device during their stay, based on the results, 97\% use Google Maps; 96\% use Facebook and its instant messaging extension; 95\% use WhatsApp; $89 \%$ use Uber transport services; $85 \%$ search videos on YouTube; and $78 \%$ use Instagram, which allows users to upload images and videos with various photographic effects. There are other programs, such as Tripadvisor (32\%) and Yelp (27\%), which are classified as tools for tourists but are used less frequently.

Regarding the source of consultation to find out about tourist sites of interest, $81 \%$ of travellers prefer social networks, $78 \%$ prefer recommendations from friends or family, 59\% examine the destination website, and $41 \%$ make use of geolocation services. Tradi- 
Table 2 Application Instrument Dimension

\begin{tabular}{|c|c|c|}
\hline Dimension & \multicolumn{2}{|c|}{ Type and number of questions Authors } \\
\hline 1 Sociodemographic profile & Multiple and dichot. choice & 6 \\
\hline $\begin{array}{l}2 \text { Information sources that you usually con- } \\
\text { sult, to find out about the tourist place }\end{array}$ & Multiple choice & $\begin{array}{l}7 \text { Santillán-Núñez et al. (2015); Saura et al. } \\
\text { (2017); Cervi (2019) }\end{array}$ \\
\hline $\begin{array}{l}3 \text { Services you use on your mobile device } \\
\text { when visiting a tourist place }\end{array}$ & Multiple choice & $\begin{array}{l}10 \text { Santillán-Núñez et al. (2015); Saura et al. } \\
\text { (2017); Ricaurte Quijano et al. (2017) }\end{array}$ \\
\hline $\begin{array}{l}4 \text { Frequency of use of digital services on the } \\
\text { mobile device during your trip (compare } \\
\text { destinations of interest, publish experi- } \\
\text { ences on social networks, etc.) }\end{array}$ & Likert scale & $\begin{array}{l}11 \text { Santillán-Núñez et al. (2015); Saura et al. } \\
\text { (2017); Ricaurte Quijano et al. (2017) }\end{array}$ \\
\hline $\begin{array}{l}5 \text { The frequency with which installed apps } \\
\text { are used which are important during the } \\
\text { trip (Facebook, YouTube, etc.) }\end{array}$ & Likert scale & $\begin{array}{l}13 \text { Santillán-Núñez et al. (2015); Saura et al. } \\
\text { (2017); Ricaurte Quijano et al. (2017); Mu- } \\
\text { nar \& Jacobsen (2014) }\end{array}$ \\
\hline $\begin{array}{l}6 \text { Level of satisfaction in the availability of } \\
\text { mobile digital services according to assess- } \\
\text { ment of the tourist during his visit at the } \\
\text { destination }\end{array}$ & Likert scale & $\begin{array}{l}8 \text { Santillán-Núñez et al. (2015); Saura et al. } \\
\text { (2017); Ricaurte Quijano et al. (2017); Yu et } \\
\text { al. (2016); Wang et al. (2012) }\end{array}$ \\
\hline
\end{tabular}

Table 3 Results of Reliability Statistics

\begin{tabular}{lrr}
\hline Item & $(1)$ & $(2)$ \\
\hline Frequency of use of digital services on the mobile device during your visit & 0.867 & 11 \\
Frequency of use of mobile applications during your visit & 0.802 & 14 \\
Satisfaction with the use of digital services available at the destination & 0.776 & 8 \\
\hline
\end{tabular}

Notes Column headings are as follows: (1) Cronbach's Alpha, (2) number of elements.

tional options - talking on the phone, travel agencies, and tour guides - are used less often.

The result of the simple correlation between the independent variable, or the frequency of use of digital services on the traveller's mobile device during their stay, and the dependent variable, which refers to the level of satisfaction obtained with these digital services in the destination, was $R=0.507$. This result indicates the total variance, which is explained in the dependent variable, product of the independent (see Table 4). Based on the value of $\$ \mathrm{R} \$$-squared, it is known that this relationship can be up to $25.7 \%$, which allows assessing the importance that digital services used on mobile devices add to travellers' experiences. These are opportunities for organizations that have the objective of continuing to build channels and improve the conditions of the technologies that must be avail-
Table 4 Simple Correlation

\begin{tabular}{ll}
\hline$R$ & 0.507 \\
$R$ square & 0.257 \\
$R$ squared corrected & 0.255 \\
Standard error of estimation & 0.558 \\
\hline
\end{tabular}

Notes Predictor variables: constant, use mobile service app trip.

able to individuals, through which a better-planned stay results and immediate access to information is obtained on purchases and security of local services and in businesses they wish to visit.

Figure 2 shows the trend of the positive mean correlation between the variables used in the simple regression procedure presented in Table 4 (independent variable: frequency of use of the digital services on 


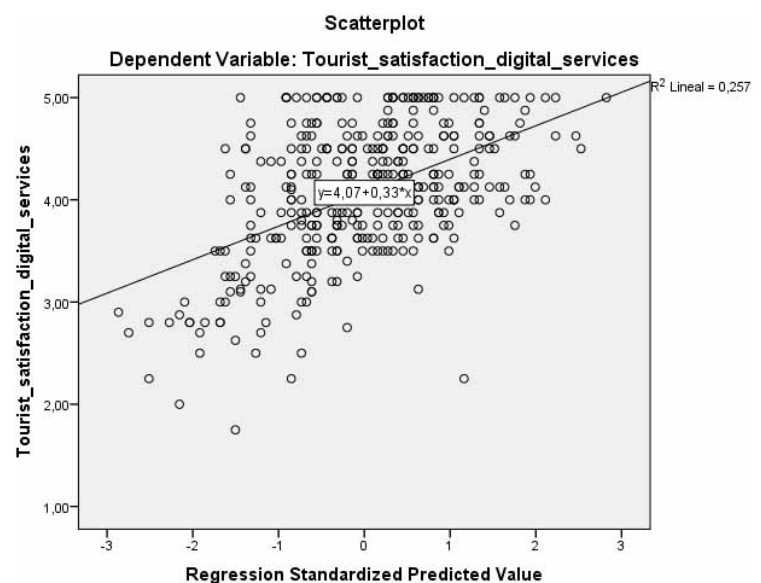

Figure 2 Scatterplot

the mobile device of the tourist during their stay; dependent variable: satisfaction obtained with the use of these digital services during their stay), which demonstrates this association represented in the scatterplot.

To reinforce this data (see table 5), a bivariate correlation was obtained through Pearson to determine the relationship between the independent variable digital services on the mobile device and the dependent variable tourist satisfaction, corresponding to the existence of a positive mean correlation of 0.507 with a significance level of 0.01 .

In addition, the results of the ANOvA test are included in Table 6, showing a significance level of 0.01 was obtained among the analysed elements, which is related to the result shown in Table 4. The alternative hypothesis is proven that the use of digital services on mobile devices contributes positively to the experience of tourists during their stay at the destination.

The results from factor analysis are discussed in the next section to identify the technological components which correspond to the digital services and tools used in mobile devices, which benefit the tourist's experience. The кмо tests and Bartlett's sphericity was performed to validate the factor analysis procedure (Pérez López, 2004); a KMO value greater than 0.5 is considered acceptable in the factor analysis model, and the closer it is to 1 , the better the adequacy of the data. By obtaining 0.884 , the data can be used for factor exposure (Table 7). The Bartlett coefficient of sphericity
Table 5 Correlations

\begin{tabular}{llrc}
\hline Item & & 1 & 2 \\
\hline 1 Use mobile & Pearson Correlation & 1 & $0.507^{* *}$ \\
service app trip & Sig. (2-tailed) & & 0.000 \\
& $N$ & 385 & 385 \\
\hline 2 Tourist satis- & Pearson Correlation & $0.507^{* *}$ & 1 \\
faction with & Sig. (2-tailed) & 0.000 & \\
digital services & $N$ & 385 & 385 \\
\hline
\end{tabular}

Table 6 Level of Significance with ANova

\begin{tabular}{lrrrrr}
\hline Item & $\begin{array}{r}\text { Sum of } \\
\text { squares }\end{array}$ & DF & $\begin{array}{r}\text { Square } \\
\text { root }\end{array}$ & $F$ & Sig. \\
\hline Regression & 41.206 & 1 & 41.206 & 132.182 & 0.000 \\
Residual & 119.396 & 383 & 0.312 & & \\
Total & 160.602 & 384 & & & \\
\hline
\end{tabular}

Notes Dependent variable: tourist satisfaction of digital services. Predictor variables: constant, use mobile service app trip.

Table 7 кмо Value and Bartlett Sphericity Test

\begin{tabular}{llr}
\hline Kaiser-Meyer-Olkin sample adequacy measure & 0.884 \\
\hline Bartlett sphericity test & Approx. $\chi^{2}$ & 4027.396 \\
& DF & 253 \\
& Sig. & 0.000 \\
\hline
\end{tabular}

derived from the process indicates that there is a correlation between the variables. This allows validating the factor analysis procedure since the derived level of significance is less than 0.05 .

Table 8 shows the percentage results of the total variance explained, which is summarized by five factors that explain 63.23\%. De la Garza et al. (2013) state that, using this criterion, $\mathrm{n}$ factors should be managed as an initial solution, as long as the percentage of accumulated explained variation ranges between 60 and 95\%.

Following the factor analysis procedure, the rotated components matrix is shown, for which the Varimax method was used (see Table 9). De la Garza et al. (2013) and Pérez López (2004) highlight that it is possible to identify a group of variables with a single simplified factor per component using this method. Therefore, 
Table 8 Total Explained Variance

\begin{tabular}{|c|c|c|c|c|c|c|c|c|c|}
\hline & \multicolumn{3}{|c|}{ Initial eigenvalues } & \multicolumn{3}{|c|}{$\begin{array}{l}\text { Sums of the saturations squared } \\
\text { of the extraction }\end{array}$} & \multicolumn{3}{|c|}{$\begin{array}{l}\text { Sum of the saturations squared } \\
\text { of the rotation }\end{array}$} \\
\hline & (1) & (2) & (3) & (1) & (2) & (3) & (1) & (2) & (3) \\
\hline 1 & 7.469 & 32.472 & 32.472 & 7.469 & 32.472 & 32.472 & 3.394 & 14.756 & 14.756 \\
\hline 2 & 2.319 & 10.082 & 42.554 & 2.319 & 10.082 & 42.554 & 3.055 & 13.283 & 28.038 \\
\hline 3 & 1.968 & 8.555 & 51.109 & 1.968 & 8.555 & 51.109 & 2.825 & 12.284 & 40.322 \\
\hline 4 & 1.545 & 6.718 & 57.827 & 1.545 & 6.718 & 57.827 & 2.756 & 11.984 & 52.307 \\
\hline 5 & 1.243 & 5.406 & 63.233 & 1.243 & 5.406 & 63.233 & 2.513 & 10.926 & 63.233 \\
\hline 23 & 0.224 & .973 & 100.000 & & & & & & \\
\hline
\end{tabular}

Notes Extraction method: principal component analysis.

the technological factors based on the digital services used on tourists' mobile devices that favour the destination experience during their stay are: (1) immediate access to destination information and services; (2) anticipated experience; (3) mobility conditions; (4) instant communication; (5) analysis of comments and opinions of available services. These factors or components integrate the digital services that contribute positively to the experience of tourists who visit the city of Tijuana. This hypothesis is verified in Table 6 . In this sense, there are areas of opportunity for companies in the tourism sector to create and/or improve marketing strategies in these digital services that benefit the stay of the tourist at the destination.

\section{Discussion}

Based on the results obtained, there is a positive average relationship between the use of digital services in the mobile devices of tourists during their stay and the level of satisfaction obtained with these digital services in the destination. In addition, tourists ensure that during their stay they use their mobile devices very often to search for information on services available at the destination, followed by use of digital maps, to search for restaurants that are of interest to them, check the weather, and review recommendations made by other users. This result coincides with the results of Chang and Shen (2018), SantillánNúnez et al. (2015), and Ricaurte Quijano et al. (2017), who indicate that people make use of the benefits of immediacy provided by current Internet technology through smartphones, for comparing the destinations they want to visit, to organize the trip, check reviews, make meteorological consultations, and use geolocation services to get around faster.

Experience is an economic factor that generates memorable events in customers (Pine II \& Gilmore, 2011). The tourist experience can become more pleasant with the support of mobile technology. It can be integrated as a personal assistant that will guide visitors in each stage of their itinerary (Santillán-Núñez et al., 2015; Bonilla, 2013). Mobile technology has become a component that contributes and brings benefits to the consumer experience (Ballesteros Díaz et al., 2014; Chang \& Shen, 2018; Saura et al., 2017). In this sense, this research found that digital services on mobile devices contribute positively to the experience of tourists in the destination visited. In addition, research results identify five factors that favour the tourist's experience through the use of smart mobile devices: immediate access to destination information and services, anticipated travel experience, resolving mobility conditions, permanent communication with the digital social environment, and analysis of comments and opinions of services available in apps for travellers.

\section{Conclusions}

The hypothesis of the research was verified: the use of digital services on the mobile devices of tourists contributes positively to the experience in the destination. 
Table 9 Rotated Component Matrix

\begin{tabular}{|c|c|c|c|c|c|}
\hline \multirow[t]{2}{*}{ Item } & \multicolumn{5}{|c|}{ Component } \\
\hline & 1 & 2 & 3 & 4 & 5 \\
\hline $\begin{array}{l}\text { Purchasing interest } \\
\text { destinations }\end{array}$ & & 0.684 & & & \\
\hline Trip organization & & 0.785 & & & \\
\hline $\begin{array}{l}\text { Information about } \\
\text { establishments }\end{array}$ & & 0.635 & & & \\
\hline Searching for reviews & & 0.766 & & & \\
\hline Book accommodation & & 0.625 & & & \\
\hline Weather consultation & & & 0.743 & & \\
\hline $\begin{array}{l}\text { Location with digital } \\
\text { map }\end{array}$ & & & 0.825 & & \\
\hline Restaurant search & & & 0.554 & & \\
\hline $\begin{array}{l}\text { Purchasing products or } \\
\text { services }\end{array}$ & 0.590 & & & & \\
\hline $\begin{array}{l}\text { Publishing reviews on } \\
\text { online sites }\end{array}$ & 0.629 & & & & \\
\hline Google maps & & & 0.705 & & \\
\hline Facebook App & & & & 0.722 & \\
\hline YouTube & 0.627 & & & & \\
\hline Google & 0.730 & & & & \\
\hline WeChat & 0.704 & & & & \\
\hline Twitter & 0.587 & & & & \\
\hline Skype & 0.658 & & & & \\
\hline Facebook Messenger & & & & 0.770 & \\
\hline WhatsApp & & & & 0.798 & \\
\hline Instagram & & & & 0.639 & \\
\hline Foursquare & & & & & 0.793 \\
\hline Yelp & & & & & 0.849 \\
\hline Tripadvisor & & & & & 0.801 \\
\hline
\end{tabular}

Notes Extraction method: principal component analysis. Rotation method: Varimax normalization with Kaiser. The rotation has converged in 7 iterations.

The digital services that stand out with factor analysis are: buy products and/or services online, search for destinations of interest, book accommodation, and use of apps such as YouTube, WeChat, Skype, Facebook, WhatsApp, Instagram, and Google maps, as well as tourist apps: Tripadvisor, Foursquare and Yelp. These services are integrated into five components: (1) imme- diate access to destination information and services; (2) advance experience; (3) mobility conditions; (4) instant communication; (5) comment analysis.

Based on the results obtained, there is a significant positive mean correlation at the 0.01 level between the frequency with which travellers use digital services through their mobile devices and the level of satisfaction they obtain regarding digital services during their stay at a destination. Likewise, based on coefficient of determination, this association can be considered $25.7 \%$. The digital services that tourists use the most on their mobile devices before and during their visit are to inquire about available service options at the site; to find restaurants; to use digital maps, which makes it possible to move more efficiently during the visit; to check weather conditions during their stay; and to consult recommendations of places of interest. These digital services are essentials on a smartphone since the sampled group consults transportation options, compares places of interest, and makes recommendations on social networks and on websites of the establishments they have been visiting.

Based on the findings of the study, mobile phones are important technological devices for tourists visiting to city of Tijuana: these benefit the traveller's experience. Therefore, it is essential for service companies in a developing country like Mexico to invest in technology to attract more tourists who demand digital services. Therefore, technology has achieved an important role for people who move to various places for vacation, rest or business. For this reason, it is recommended to intensify campaign strategies for tourism attention and content aimed at this market. Thus, it is essential to make available applications that contain special information for tourists, which they can use to make better decisions.

The current environment of tourism in developing countries, where mobile phones function as a means of consultation, verification and identification in some services, displacing physical contact for some activities, has caused many of the tourist services to complete their technological transition to smartphones, in order to avoid losing connection between company and user. Therefore, in the context of tourism organizations in the city of Tijuana, it becomes a necessity 
to highlight their products in a smartphone format.

Research limitations highlight the need to use a larger sample to distribute it by means of a stratified selection with proportional allocation in other municipalities in Baja California that also have a considerable influx of visitors, for comparing the use of digital services and apps in smart mobile devices, and to include tourists who do not use these technological tools in sampling.

\section{References}

Andrade Yejas, D. A. (2016). Estrategias de marketing digital en la promoción de Marca Ciudad. Revista Escuela De Administración De Negocios, 80, 59-72.

Arévalo-Avecillas, D., Nájera-Acuña, S., \& Piñero, E. (2018). La influencia de la implementación de las tecnologías de información en la productividad de empresas de servicios. Información Tecnológica, 29(6), 199-212.

Arnould, E., \& Price, L. (1993). River magic: Extraordinary experience and the extended services encounter. Journal of Consumer Research, 2o(1), 24-45.

Ballesteros Díaz, B., Tavera Mesías, J., \& Castaño Serna, D. (2014). Aceptación tecnológica de la publicidad en dispositivos móviles en Colombia. Semestre Económico, 17(36), 133-153.

Bigné, E., Sánchez, I., \& Currás Pérez, R. (2011). Antecedentes y consecuencias del arrepentimiento postcompra: una aplicación a servicios de telefonía móvil. Revista Española de investigación de marketing, 15(1), 7-34.

Bonilla, J. (2013). Nuevas tendencias del turismo y las tecnologías de la información y las comunicaciones. Anuario Turismo y Sociedad, 14, 33-45.

Bringas, N., Díaz-Bautista, A., \& González, S. (2004). Economía sectorial de la frontera norte. Economía Informa, $327,68-82$.

Brumen, B., Planinc, P., Špindler, T., Gorenak, M., \& Lešnik, T. (2020). Use of mobile technologies in tourism: Natural health resorts study. Mediterranean Journal of Social Sciences, 11(4), 1-18.

Caro, J., Luque, A., \& Zayas, B. (2015). Nuevas tecnologías para la interpretación y promoción de los recursos turísticos culturales. Pasos: Revista de Turismo y Patrimonio Cultural, 13(4), 931-945.

Carrizo Moreira, A., Freitas, P., \& Ferreira, V. (2017). Efectos de las experiencias de marca en la calidad, la satisfacción y la lealtad: Estudio empírico en el sector de servicios múltiples de telecomunicaciones. Innovar, 27(64), 23-36.

Carrizo Moreira, A., \& Silva, P. M. (2015). The trust-commitment challenge in service quality-loyalty relationships.
International Journal of Health Care Quality Assurance, 28(3), 253-266.

CEMDI. (2015). Tijuana en cifras. https://cemdi.org.mx/docs /publications/W.BOOK\%20TIJUANA\%202016.pdf

Cervi, L. (2019). Comunidades virtuales de viajeros: un caso de éxito Universitas. Universitas: Revista de Ciencias Sociales y Humanas, 30, 97-125.

Chang, S. E., \& Shen, W.-C. (2018.). Exploring smartphone social networking services for mobile tourism. International Journal of Mobile Communications, 16(1), 63-81.

Chung, K., \& Shin, J. (2010). The antecedents and consequents of relationship quality in internet shopping. Asia Pacific Journal of Marketing and Logistics, 22(4), 473-491.

Clarke, I. (2001). Emerging value propositions for $\mathrm{m}$-commerce. Journal of Business Strategies, 18(2), 133-148.

Constantinides, E. (2004). Influencing the online consumer's behavior: The Web experience. Internet Research, 14(2), $111-126$.

COPLADE. (2017). Tijuana. http://www.copladebc.gob.mx /publicaciones/2017/Mensual/Tijuana\%202017.pdf

Cvitić, F., \& Plenković, M. (2018). Attracting user's attention for travelling purposes via visual messages. Academica Turistica, 11(1), 3-18.

Daries-Ramón, N., Cristóbal-Fransi, E., Martín-Fuentes, E., \& Marine-Roig, E. (2016). Adopción del comercio electrónico en el turismo de nieve y de montaña: Análisis de la presencia web de las estaciones de esquí a través del modelo e mic A. Cuadernos de Turismo, 37, 113-134.

DataTur. (N.d.). Reportes. https://www.datatur.sectur.gob.mx :81/Reportes/Reportes.aspx

Davis, R., Sajtos, L., \& Chaudhri, A. (2011). Do consumers trust mobile service advertising? Contemporary Management Research, 7(4), 245-270.

De la Garza, J., Morales, B. N., \& González, B. A. (2013). Análisis Estadístico Multivariante: Un enfoque teótico y práctico. McGraw-Hill.

De Freitas Coelho, M., \& Feder Mayer, V. (2020). Gestão de serviços pós-covid: o que se pode aprender com o setor de turismo e viagens? Gestão \& Sociedade, 14(39), 36983706.

Dickinson, J., Ghali, K., Cherrett, T., \& Norgate, S. (2014). Tourism and the smartphone app: Capabilities, emerging practice and scope in the travel domain. Journal Current Issues in Tourism, 17(1), 84-101.

Domínguez Vila, T., \& Araújo Vila, N. (2014). Gestión de las redes sociales turísticas en la web 2.o. Vivat Academia, 129, 57-78.

Egan, J. (2011). Relationship marketing: Exploring relational strategies in marketing (4th. ed.). Prentice Hall. 
Ferrá, F. C. M, \& Cardona, J. R. (2015). Presencia de las cadenas hoteleras españolas en los medios sociales. Cultur - Revista de Cultura e Turismo, 9(1), 5-35.

Fischer, L., \& Espejo, J. (2017). Introducción a la investigación de mercados. McGraw-Hill.

Giraldo Cardona, M., \& Martínez, S. M. (2017). Análisis de la actividad y presencia en Facebook y otras redes sociales de los portales turísticos de las Comunidades Autónomas españolas. Cuadernos De Turismo, 39, 239-264.

González-Damián, A. (2018). Construcción Social de la experiencia turística. Bubok Publishing.

Hernández Sampieri, R., Fernández Collado, C., \& Baptista Lucio, P. (2014). Metodología de la Investigación. McGraw Hill.

Hinton, P., Mcmuray, I., \& Browlow, C. (2014). spss Explained. Routledge.

Holbrook, M., \& Hirschman, E. (1982). The experiential aspects of consumption: Consumer fantasies, feelings, and fun. Journal of Consumer Research, 9(2), 132-140.

Huertas, A., \& Marine-Roig, E. (2018). Searching and sharing of information in social networks during the different stages of a trip. Cuadernos de Turismo, 42, 185-212.

Internet Association of Mexico. (2018). 14 Estudio sobre los hábitos de los usuarios de Internet en México 2018. Asociación de Internet $\mathrm{Mx}$. https://www .asociaciondeinternet.mx/estudios/habitos-de-internet

Iványi, T., \& Bíró-Szigeti, S. (2019). Smart city: Studying smartphone application functions with city marketing goals based on consumer behavior of generation $\mathrm{Z}$ in Hungary. Periodica Polytechnica: Social y Management Sciences, 27(1), 48-58.

Ivars, J. A., Solsona, F. J., \& Giner, D. (2016). Gestión turística y tecnologías de la información y la comunicación (TIC): El nuevo enfoque de los destinos inteligentes. Documents d’Anàlisi Geogràfica, 62(2), 327-346.

Kang, M., \& Schuett, M. (2013). Determinants of sharing travel experiences in social media. Journal of Travel \& Tourism Marketing, 3o(1), 93-107.

Katsoni, V. (2014). The strategic role of virtual communities and social network sites on tourism destination marketing. e-Journal of Science y Technology, 9(5), 107-117.

Kavoura, A., \& Borges, M. T. T. (2016). Understanding online communities on social networks via the notion of imagined communities: The case of Tripdvisor. International Journal of Web Based Communities, 12(3), 238-261.

Lamberton, C., \& Stephen, A. T. (2016). A thematic exploration of digital, social media, and mobile marketing: $\mathrm{Re}-$ search evolution from 2000 to 2015 and an agenda for future inquiry. Journal of Marketing, 8o(6), 146-172.
Litvin, S., \& Dowling, K. (2016). TripAdvisor and hotel consumer brand loyalty. Current Issues in Tourism, 21(8), $842-846$.

Malhotra, N. K. (2008). Investigación de Mercados. Pearson Educación.

Maráková, V., \& Kvasnová, D. (2016). Cooperation as a driving forcé of innovations in destination marketing management. Forum Scientiae Oeconomia, 4(3), 67-79.

Mazarrasa, K. (2016). Experiential and creative tourism: The case of Cantabria. International Journal of Scientific Management and Tourism, 2(3), 195-203.

Mendes-Thomaz, G., Biz, A. A., \& Gândara, J. M. (2013). Innovación en la promoción turística en medios y redes sociales: Un estudio comparativo entre destinos turísticos. Estudios y perspectivas en turismo, 22(1), 102-119.

Munar, A., \& Jacobsen, J. (2014). Motivations for Sharing tourism experiences through social media. Tourism Management, 43, 46-54.

Naciones Unidas. (2020). Informe de políticas: La COVID-19 y la transformación del turismo. https://www.un.org/sites /un2.un.org/files/policy_brief_covid-19_and _transforming_tourism_spanish.pdf

Narváez Castro, M., \& Villalobos Jiménez, K. (2020). Perfil social business para el marketing de empresas turísticas de Paraguaná, Venezuela. Revista de Ciencias Sociales, 26(1), 287-299.

Neuhofer, B., Buhalis, D., \& Ladkin, A. (2013). A typology of technology-enhanced tourism experiences. International Journal of Tourism Research, 16(4), 340-350.

Nikunen, T., Saarela, M., Oikarinen, E., Muhos, M., \& Isohella, L. (2017). Micro-enterprises' digital marketing tools for building customer relationships. Management, 12(2), 171-188.

Okazaki, S., \& Hirose, M. (2009). Does gender affect media choice in travel information search? On the use of mobile Internet. Tourism Management, 30(6), 794-804.

Oviedo, H. C., \& Campo-Arias, A. (2005). Aproximación al uso del coeficiente alfa de Cronbach. Revista Colombiana de Psiquiatría, 34(4), 572-580.

Pérez López, C. (2004). Técnicas de análisis multivariante de datos. Pearson Educación.

Pérez-Almaguer, Y., Medina-Labrada, J., \& Nápoles, L. (2015). Atributos que determinan la decisión de compra. Retos Turísticos, 14(3), 17-26.

Pine II, J., \& Gilmore, J. (2011). The experience economy. Harvard Business Review Press.

Ricaurte Quijano, C., Arellano Augusto, A., \& Naranjo Salavarria, K. (2017). (Des)conexión durante el viaje turístico: uso de Smartphone por parte de viajeros indepen- 
dientes en la ciudad de Guayaquil. Teoría y Praxis, 23, 93-119.

Rivera Mateos, M. (2013). El turismo experiencial como forma de turismo responsable e intercultural. Relaciones interculturales en la diversidad, 1, 199-217.

San Martín, S., \& Pradanova, J. (2014). ¿Qué factores fomentan la compra por impulso en el comercio móvil? Revista Española de Investigación de Marketing ESIC, 18, 32-42.

Santillán-Núñez, M. A., Velarde-Valdez, M., \& ObomboMagio, K. (2015). Tecnologías de Información y Comunicación al servicio del turismo en Mazatlán. Ciencias Holguín, 21(1), 1-10.

Sarmiento Guede, J. R., \& Ferrão Filipe, A. J. (2019). La eexperiencia de marca a través de los medios sociales y su influencia en la e-calidad de la relación y la efidelización: análisis empírico en los sitios web de viajes. Cuadernos de turismo, 44(219), 351-380.

Saura, J. R., Palos-Sánchez, P., \& Reyes-Menéndez, A. (2017). Marketing a través de aplicaciones móviles de turismo ( $\mathrm{m}$-tourism): un estudio exploratorio. International Journal of World of Tourism, 4(8), 45-56.

SECTUR. (2013). Programa sectorial de turismo 2013-2018. http://www.sectur.gob.mx/pdf/PlaneacionTuristica /Prosectur_2013_2018.pdf

SECTUR. (2018). Visión global del turismo a México. https:// www.datatur.sectur.gob.mx/Documentos \%2ocompartidos/VisionGlobalTurismoAMexAbr2018 .pdf

Sukno, R., \& Pascual, M. I. (2019). E-commerce C2C en Chile: incorporación de la reputación y de la confianza en el TA M. Journal of Technology Management \& Innovation, 14(3), 72-78.

Szymanski, D., \& Hise, R. (200o). E-satisfacción: un examen inicial. Journal of Retailing, 76(3), 309-322.

Tafur, G., Vélez, C., Alejo, O. J., \& Zumba, M. (2019). Análisis crítico de la gestión tecnológica en la industria turística del Guayas, Ecuador. Revista Espacios, 40(37), 1-12.

UnwTo. (2015, January 29). Technology at the service of tourism for all. https://www.unwto.org/archive/global /event/technology-service-tourism-all
UNWTO. (2018, November 2). UNWTO calls for tech and investment in tourism at world travel market 2018. https:// www.unwto.org/global/press-release/2018-11-02/unwto -calls-tech-and-investment-tourism-world-travel -market-2018

Unwto. (2020, March 25). Calling on innovators and entrepreneurs to accelerate tourism recovery. https://www .unwto.org/calling-on-innovators-and-entrepreneurs -to-accelerate-tourism-recovery

Varkaris, E., \& Neuhofer, B. (2017). The influence of social media on the consumers' hotel decision journey. Journal of Hospitality and Tourism Technology, 8(1), 101-118.

Velázquez Castro, J. A., Cruz Coria, E., \& Vargas Martinez, E. E. (2018). Cooperación empresarial para el fomento de la innovación en la pyme turística. Revista de Ciencias Sociales, 24(3), 9-20.

Wang, D., Sangwon, P., \& Fesenmaier, D. (2012). The role of smartphones in mediating the touristic experience. Journal of Travel Research, 51(4), 371-387.

Werthner, H., Alzua-Sorzabal, A., \& Cantoni, L. (2015). Future research issues in IT and tourism. Information Technology \& Tourism, 15(1), 1-15.

Yu, Z., Xu, H., Yang, Z., \& Guo, B. (2016). Personalized Travel package with multi-point-of-interest recommendation based on crowdsourced user footprints. IEEE Transactions on Human-Machine Systems, 46(1), 151-158.

Zarantonello, L., \& Schmitt, B. (2010). Using the brand experience scale to profile consumers and predict consumer behaviour. Journal of Brand Management, 17(7), 532-540.

Zeng, B., \& Gerritsen, R. (2014). What do we know about social media in tourism? A review. Tourism Management Perspectives, 10, 27-36.

Zhang, T., Cheung, C., \& Law, R. (2018). Functionality evaluation for destination marketing websites in smart tourism cities. Journal of China Tourism Research, 14(3), 263278 . 